Association for Information Systems AIS Electronic Library (AISeL)

AMCIS 2003 Proceedings

Americas Conference on Information Systems

(AMCIS)

December 2003

\title{
New Perspectives on Global Information Systems Journal Rankings and Reference Disciplines
}

Paul Lowry

Brigham Young University

Denton Romans

Brigham Young University

Follow this and additional works at: http://aisel.aisnet.org/amcis2003

\section{Recommended Citation}

Lowry, Paul and Romans, Denton, "New Perspectives on Global Information Systems Journal Rankings and Reference Disciplines" (2003). AMCIS 2003 Proceedings. 367.

http://aisel.aisnet.org/amcis2003/367

This material is brought to you by the Americas Conference on Information Systems (AMCIS) at AIS Electronic Library (AISeL). It has been accepted for inclusion in AMCIS 2003 Proceedings by an authorized administrator of AIS Electronic Library (AISeL). For more information, please contact elibrary@aisnet.org. 


\title{
NeW PERSPECTIVES ON GLOBAL INFORMATION SySTEMS JOURNAL RANKINGS AND REFERENCE DISCIPLINES
}

\author{
Paul Benjamin Lowry \\ Brigham Young University \\ Marriott School of Management \\ Paul.Lowry@BYU.edu
}

\author{
Denton Romans \\ Brigham Young University
}

\begin{abstract}
This article overviews the results of the largest, global study focusing on perceived rankings of Information Systems (IS) journals and IS reference disciplines. 8741 faculty were emailed from 414 global IS departments (738 of the emails were not valid). 2559 responses were received for a 32\% response rate. This study did not use pre-determined journal lists, but instead required respondents to list their top-four research journals using free recall. Additionally, this study reports journal ratings for the top IS practitioner journals, the most read IS journals, and the top journals for the most common IS reference disciplines. While the results of this study have many potential benefits in defining the current state of the IS field and for helping guide academic evaluations, such studies should not be used as a primary factor in tenure and promotion decisions; instead, such rankings data needs to be used with sound judgment, in conjunction with other ratings methodologies.
\end{abstract}

\section{Introduction}

The purpose of this article is to overview the results of a unique global study on Information Systems (IS) journal rankings and IS reference disciplines. First, the benefits of journal rankings studies are overviewed. Second, a review of previous journal rankings research is presented. Third, based on this literature review, several opportunities for further study are identified, which this research builds on. Fourth, a survey of over 8700 IS academics is described along with its empirical results. Finally, the results of this study are discussed, along with its unique contributions and limitations.

IS journal ranking studies tend to have a galvanizing effect on the IS research community, as some researchers embrace the results as an important source of defining the structure of the field, yet others claim such ratings have a pernicious effect on academic freedom. While journal ratings can be misused, they can provide several benefits to the IS community: (1) Journal rankings help researchers know where to find leading research (Hamilton \& Ives, 1980). (2) They help researchers find appropriate publishing outlets (Hamilton \& Ives, 1980). (3) They encourage improvement and self-analysis by journal editors. (4) They help libraries decide where to invest scarce funds for acquiring journals. (5) They help practitioners know where to discover leading information on IS. (6) They provide a useful source of information for evaluating the quality of an academic's publications for promotion and tenure decisions (Hamilton \& Ives, 1980). (7) They provide insights on what academics consider to be the leading journals at any given time, which is useful since the importance of particular journals continually evolves over time.

The two methodologies that are typically used for journal rankings are citation analysis and surveys. To some, citation analysis inherently feels more objective and precise than surveys based on perceptions of experts, because citation analyses are based on empirical data extracted from published journals. Citation analyses are traditionally used to show the productivity of individual researchers or institutions, based on the number of times a given work is cited. However, variations of this research have also been used to help define the top journals in a given field. An example study uses citation analysis to measure journal influence in IS (Cooper, Blair, \& Pao, 1993). Holsapple (Holsapple, Johnson, Manakyan, \& Tanner, 1994; Holsapple, Johnson, Manakyan, \& Tanner, 1993; Holsapple, Manakyan, \& Tanner, 1995) ranks journals according to citations for the fields of DSS and Business Computing Research. 
One limitation of citation analyses is that researchers still must subjectively define what is and what is not IS research, and then must rate each article in each selected journal as to whether or not it meets the inclusion criteria. Ironically, most citation analyses select a small number of journals to target, based on small, subjective samplings of external experts-limiting the results to those selected journals. Other limitations of citation analysis include that self-citation policies greatly vary by journal, and citations can be biased toward journals that have been existence the longest. Additionally, the number of pages, average number of articles, and the number of times a journal is published each year greatly varies by journal, which can create biases toward journals that are published more often and/or produce more articles, because increased numbers of published works inflates the works that are available for citation. Finally, one or two hallmark articles can be cited disproportionately and distort such rankings.

Turning from citation analysis, surveying IS academics is the most common approach to assess journal quality. One reason for its popularity is that academics make the primary evaluations of each other's journal articles, in making decisions for promotion, general recognition, and tenure. Thus, journal surveys essentially peer into the minds of those who are making such decisions. Table 1 summarizes the major IS-related journal ranking survey studies that have been published (this excludes studies that summarize other studies or provide non-empirical rankings, such as) (Davis, 1980; Nord \& Nord, 1995; Nord \& Nord, 1990; Robey, Walstrom, Adams, \& Swanson, 2000).

Previous surveys have been widely used and have made significant contributions to the IS field; however, they also have room for improvement. First, they often use pre-selected, alphabetized lists of IS journals, which can introduce potential ordering, memory, familiarity, fatigue, and selection biases. For example, some journals may receive higher rankings based on the familiarity of their name or based on early appearance in a journal list. Additionally, the use of large lists can cause fatigue and other unintended results, especially when respondents have vague familiarity with many of the journals, yet choose to rank them anyway. Long lists can also cause many low-quality journals to be ranked that would not otherwise be considered, and such lists can often exclude journals that researchers find salient. On the other hand, such lists can provide significant value in providing a representation distribution of high-quality, medium-quality, and low-quality journals, as seen in (Mylonopolous \& Theoharakis, 2001). IS journal rankings may also benefit by including more information, such as demographic data that would allow researchers to remove less-actives members of the IS community. It may also be useful to separate journal rankings based on journal type, such as research versus academic; and to provide rankings of journals used by IS researchers who publish in specific reference disciplines, such as Computer Science and Business Administration. Such studies would also benefit by providing more global data, so that differences in world regions can be examined, as seen in (Mylonopolous \& Theoharakis, 2001), which is the only journal ranking study that has focused on the global IS community.

Given the opportunities created by previous studies, this research provides another perspective on determining IS journal quality, by extending previous ranking studies in several important ways: (1) Including the largest selection of global respondents ever targeted for such a study. (2) Asking respondents to rank only their top journal choices. (3) Removing respondents who are members of IS departments but do not consider themselves to be active members of the IS academic community. (4) Requiring respondents to use free recall to list their top four IS research journals. (5) Weighting rankings according to rank order of the journals. (6) Including journal rankings for practitioner journals, readership, and the most common reference disciplines for IS researchers.

\section{Survey Method}

This section discusses the method that was used to conduct this survey research. First, the targeted participants are described. Next, the instrument and procedures used for this study are reviewed. The results of the analysis are shown in section 3.0, and are then discussed thoroughly in section 4.0.

The target population for this study consists of all active IS academics throughout the world. Finding appropriate representation of this population proved to be a difficult task. Most journal rankings have relied on published IS faculty directories, which can suffer from the lack of current data, lack of complete data, and lack of global representation. An effective approach was recently used where researchers targeted both the IS World listserv and the IS Faculty Directory on www.isworld.org (Mylonopolous \& Theoharakis, 2001). However, a few issues still exist with this approach: (1) The IS World listserv contains many students, which cannot be directly filtered out. (2) Hundreds of the listings on the IS Faculty Directory are not current or accurate (as seen by the fact that nearly one third of the emails in the Mylonopolous were invalid), because this data is voluntarily created and updated by each participating academic. (3) The names and institutions of those subscribing to the IS World listserv are not publicly available; thus, it is difficult to estimate a correct sample size when significant overlap exists between the IS World listserv and the IS Faculty Directory. 
Table 1. All Major IS Journal Ranking Survey Studies

\begin{tabular}{|c|c|c|c|c|}
\hline Who/When & Key Aspects of the Study & $\begin{array}{c}\text { Journal } \\
\text { Selection }\end{array}$ & Respondent Selection & Participation \\
\hline $\begin{array}{l}\text { Hamilton \& } \\
\text { Ives, } 1980\end{array}$ & $\begin{array}{l}\text { Combined journal rankings survey } \\
\text { with citation analysis of productivity. } \\
\text { Journal survey asked participants to } \\
\text { rate how each journal contributes to } \\
\text { the MIS field and the extent to which } \\
\text { they are read. }\end{array}$ & $\begin{array}{l}\text { Used a predeter- } \\
\text { mined list of } 37 \\
\text { journals }\end{array}$ & $\begin{array}{l}\text { Targeted } 291 \text { MIS } \\
\text { experts, as determined by } \\
\text { the authors. }\end{array}$ & $\begin{array}{l}110 \text { responses } \\
(37.8 \% \text { response } \\
\text { rate) }\end{array}$ \\
\hline $\begin{array}{l}\text { Vogel \& } \\
\text { Wetherbe, } 1984\end{array}$ & $\begin{array}{l}\text { Asked respondents for the academic } \\
\text { journals they prefer to publish in. } \\
\text { Ranked journals in descending order } \\
\text { and weighted according to the } \\
\text { ranking order. provided empirical } \\
\text { data to show what journals the top IS } \\
\text { programs were publishing in. }\end{array}$ & $\mathrm{n} / \mathrm{a}$ & $\begin{array}{l}291 \text { IS experts were } \\
\text { selected. }\end{array}$ & $\begin{array}{l}110 \text { responses } \\
(37.8 \% \text { response } \\
\text { rate })\end{array}$ \\
\hline $\begin{array}{l}\text { Doke \& Luke, } \\
1987\end{array}$ & $\begin{array}{l}\text { Asked for top-10 IS; computed a } \\
\text { popularity/familiarity index and an } \\
\text { importance/prestige index. }\end{array}$ & $\begin{array}{l}\text { Used a predeter- } \\
\text { mined list of } 29 \\
\text { journals }\end{array}$ & $\begin{array}{l}\text { Sent to } 243 \text { Deans of } \\
\text { US/Canada AACSB } \\
\text { schools who distributed } \\
\text { to their IS faculty. Only } \\
93 \text { of the schools had IS } \\
\text { departments. }\end{array}$ & $\begin{array}{l}29 \text { schools } \\
\text { responded with } \\
82 \text { usable } \\
\text { responses ( } 31 \% \\
\text { corrected rate) }\end{array}$ \\
\hline $\begin{array}{l}\text { Koong \& } \\
\text { Weistroffer, } \\
1989\end{array}$ & $\begin{array}{l}\text { Asked respondents to list the three } \\
\text { most used journals for acquiring MIS } \\
\text { information and the three most used } \\
\text { for publishing. }\end{array}$ & $\begin{array}{l}\text { Used a predeter- } \\
\text { mined list of } 70 \\
\text { journals, allowed } \\
\text { write-ins }\end{array}$ & $\begin{array}{l}\text { Used published directory } \\
\text { of MIS faculty (using a } \\
\text { sequential random sample } \\
\text { of 500). }\end{array}$ & $\begin{array}{l}144 \text { people } \\
\text { responded } \\
(28.7 \% \text { response } \\
\text { rate })\end{array}$ \\
\hline $\begin{array}{l}\text { Gillenson \& } \\
\text { Stutz, } 1991\end{array}$ & $\begin{array}{l}\text { Assessed attitudes of professors on } \\
\text { the academic quality of MIS journals } \\
\text { based on their value in reviews of } \\
\text { research and performance of } \\
\text { individual MIS researchers. }\end{array}$ & $\begin{array}{l}\text { Used a pre- } \\
\text { determined list of } \\
80 \text { journals }\end{array}$ & $\begin{array}{l}\text { Selected department chair } \\
\text { or most senior person } \\
\text { from } 269 \text { US/Canada } \\
\text { AACSB accredited } \\
\text { business schools. }\end{array}$ & $\begin{array}{l}135 \text { respondents } \\
(50.2 \% \text { response } \\
\text { rate })\end{array}$ \\
\hline $\begin{array}{l}\text { Whitman, } \\
\text { Hendrickson, \& } \\
\text { Townsend, } 1999\end{array}$ & $\begin{array}{l}\text { Asked respondents to rate journals as } \\
\text { top, high, medium, low, and nil } \\
\text { (assigned numerical value); also } \\
\text { asked for tenure and promotion } \\
\text { related data }\end{array}$ & $\begin{array}{l}\text { Used a predeter- } \\
\text { mined list of } 80 \\
\text { journals }\end{array}$ & $\begin{array}{l}\text { Sent survey to } 432 \\
\text { department heads in } \\
\text { US/Canada, using } 1995 \\
\text { directory of MIS faculty. }\end{array}$ & $\begin{array}{l}184 \text { responded } \\
(43 \% \text { response } \\
\text { rate) }\end{array}$ \\
\hline $\begin{array}{l}\text { Walstrom \& } \\
\text { Hardgrave, } 2001\end{array}$ & $\begin{array}{l}\text { Extended their earlier studies } \\
\text { (Walstrom, Hardgrave, \& Wilson, } \\
\text { 1995; Hardgrave \& Walstrom, 1997). } \\
\text { Asked each respondent to numeri- } \\
\text { cally rate each journal on its appro- } \\
\text { priateness to MIS on a scale of one to } \\
\text { four. }\end{array}$ & $\begin{array}{l}\text { Latest study had } \\
\text { pre-determined } 15 \\
\text { journals and } 13 \\
\text { conferences }\end{array}$ & $\begin{array}{l}\text { Targeted only } \\
\text { US/Canadian } \\
\text { respondents. }\end{array}$ & 350 responses \\
\hline $\begin{array}{l}\text { Mylonopolous \& } \\
\text { Theoharakis, } \\
2001\end{array}$ & $\begin{array}{l}\text { Asked for top-10 journals in } 1 \text { st tier } \\
\text { and top-10 journal in } 2 \text { nd tier, and } \\
\text { most read journals. First global } \\
\text { survey; also students. }\end{array}$ & $\begin{array}{l}\text { Used a predeter- } \\
\text { mined list of } 87 \\
\text { journals }\end{array}$ & $\begin{array}{l}\text { Emailed } 3855 \text { academics } \\
\text { from ISWorld faculty } \\
\text { directory, including } \\
\text { students; } 1094 \text { emails } \\
\text { were not valid. }\end{array}$ & $\begin{array}{l}979 \text { usable } \\
\text { responses; } \\
(35.5 \% \text { corrected } \\
\text { response rate) }\end{array}$ \\
\hline This study & $\begin{array}{l}\text { Produced the largest, global study; } \\
\text { primary focus on top-tier journals; } \\
\text { adds top journals for reference } \\
\text { disciplines, top read journals, and top } \\
\text { practitioner journals. }\end{array}$ & $\begin{array}{l}\text { Did not use pre- } \\
\text { determined lists; } \\
\text { uses free recall of } \\
\text { top journals }\end{array}$ & $\begin{array}{l}414 \text { global IS } \\
\text { departments; emailed } \\
8741 \text { faculty; } 738 \text { emails } \\
\text { were not valid. }\end{array}$ & $\begin{array}{l}2559 \text { responses } \\
(32 \% \text { response } \\
\text { rate); } 1752 \text { fully } \\
\text { active in IS }\end{array}$ \\
\hline
\end{tabular}


Given the sampling challenges experienced in previous studies, we chose a new sampling method by building a list of IS academics, by visiting the websites of all 414 global departments listed on the AIS (Association for IS) directory and extracting all IS-related faculty members. Given the multidisciplinary nature of the field, we surmised this approach would not only find most of the active IS academics in the world, but would also extract many of their colleagues who are in IS departments but do not consider themselves an active part of the field. In this way, we chose to over sample the population and then let academics identity their activity in IS (with those not involved in IS to be most likely not to respond). This was a useful approach because trying to determine from online vitas whether or not a person is an active IS academic is highly subjective (e.g. several academics may publish in IS journals on occasion but do not consider IS to be their main discipline, and many IS academics also publish in non-IS journals).

Our approach appears to be highly successful—we created a large target sample of 8741 individuals and achieved a high response rate. These individuals were solicited by email to participate in the web-based survey. Of these, 738 email addresses were invalid (8.4\%), leaving 8003 valid email recipients - which suggests the department listings we used were more current than the IS World Faculty directory. From the valid list of 8003 participants, 2559 responses were received. This represents a response rate of $32 \%$, which is notable especially considering many of the sampled targets may not be members of the IS field who chose not to respond to an IS survey.

By achieving a high response rate of the global population of IS academics, this study provides insights into the composition of IS departments throughout the world. The vast majority of the 2559 respondents were male and Caucasian. The gender distribution in the departments is $79.3 \%$ male and $20.7 \%$ female. Of these respondents, only a slight majority consider themselves to be primarily aligned with the field of IS-significant minorities consider themselves to be members of CS and Business academic communities, even though they reside in IS departments. To provide the most relevant and reliable results to the IS community, only respondents who considered themselves primarily aligned with the IS field and have Ph.D.'s were included in the journal ranking results (students, inactive IS researchers, and those not holding Ph.D.'s were excluded). Thus, the number of responses that were used for journal rankings decreased from 2559 to 1572 . Nearly half of the selected respondents were senior faculty (full or associate professors).

The instrument that was used was a web-based survey that not only examined journal rankings, but also probed for extensive, global demographic information, such as levels of activity in the IS field. Three general notices were sent out to the participants over a period of several weeks to encourage them to participate in the study. Because sensitive demographic data was solicited, respondents were allowed to respond anonymously. Measures were taken to remove multiple submissions from the same computer to prevent "ballot stuffing" or accidental duplicate submissions.

\section{Survey Analysis}

The primary analysis conducted by this research was to assess the top perceived IS journals. Participants ranked up to four choices as to what they perceive to be the top IS research journals. All rankings were weighted as follows: first place received four points, second place received three points, third place received two points, and fourth place received one point. Table 2 summarizes the top-25 research journals for all world respondents (Appendix 1 lists the abbreviations used in this study). Table 3 compares the summary of world results of this study versus several previous journal ranking studies (See Appendix for Tables 3 and 4). Table 4 shows the top-rated practitioner journals. Table 5 shows the most read journals, both practitioner and research.

In addition, respondents were asked to optionally name their most frequently used reference or support disciplines, and the top-two journals for publishing in these disciplines as an active IS researcher. While not all respondents completed this information, the results still provide valuable information on the most common IS reference disciplines and reference discipline journals that IS researchers publish in. Table 6 shows that the top reference discipline for IS researchers throughout the world is Computer Science, the second is Business, and the third is Behavioral Science. Tables 11-13 list the top journals for the top seven reference discipline in which active IS researchers publish (journals for the remaining disciplines are not listed as the number of respondents for each discipline was less than 50; only journals with weightings greater than six are listed). 
Table 2. Journal Rankings by World Regions

\begin{tabular}{|c|l|c|l|c|l|c|l|c|l|c|}
\hline Rank & \multicolumn{1}{|c|}{ World } & Weight & $\begin{array}{c}\text { North } \\
\text { America }\end{array}$ & Weight & Australasia & Weight & Europe & Weight & Other & Weight \\
\hline 1 & MISQ & 2277 & MISQ & 1431 & MISQ & 401 & MISQ & 255 & MISQ & 155 \\
\hline 2 & ISR & 1806 & ISR & 1277 & ISR & 250 & ISR & 152 & ISR & 91 \\
\hline 3 & JMIS & 649 & JMIS & 512 & CACM & 71 & CACM & 58 & CACM & 33 \\
\hline 4 & MS & 598 & MS & 459 & JMIS & 70 & EJIS & 39 & MS & 32 \\
\hline 5 & CACM & 457 & CACM & 287 & MS & 70 & ISJ & 28 & JMIS & 26 \\
\hline 6 & DSCI & 139 & DSCI & 121 & I\&M & 27 & JMIS & 28 & I\&M & 13 \\
\hline 7 & DSS & 134 & DSS & 104 & EJIS & 24 & MS & 21 & IEEET & 10 \\
\hline 8 & IEEET & 116 & IEEET & 67 & IEEET & 24 & HBR & 19 & ACMT & 9 \\
\hline 9 & I\&M & 90 & OS & 46 & ACMT & 21 & WIRT & 19 & DSCI & 9 \\
\hline 10 & ACMT & 82 & JAIS & 44 & ISJ & 20 & ACMT & 15 & JSIS & 8 \\
\hline 11 & EJIS & 76 & I\&M & 41 & JAIS & 18 & IEEET & 15 & ISJ & 6 \\
\hline 12 & JAIS & 67 & ACMT & 36 & DSS & 10 & I\&O & 14 & DSS & 5 \\
\hline 13 & ISJ & 66 & JOC & 29 & JIS & 9 & ISYS & 13 & IM & 5 \\
\hline 14 & OS & 59 & OR & 27 & DSCI & 8 & JSIS & 13 & JAIS & 5 \\
\hline 15 & HBR & 41 & JCIS & 20 & JSIS & 8 & DSS & 10 & ACMTCS & 4 \\
\hline 16 & JOC & 36 & IEEETSE & 16 & IEEES & 7 & ACMTOIS & 9 & ACMTODS & 4 \\
\hline 17 & OR & 34 & JIS & 16 & IJEC & 7 & OS & 9 & ASQ & 4 \\
\hline 18 & JSIS & 33 & DATA & 14 & IT\&P & 7 & I\&M & 8 & HBR & 4 \\
\hline 19 & JIS & 31 & HBR & 13 & ISYS & 7 & ACMTOCHI & 7 & IT\&P & 4 \\
\hline 20 & I\&O & 24 & IEEEC & 13 & JIT & 7 & HCI & 7 & ISOC & 4 \\
\hline 21 & ISYS & 24 & ISJ & 12 & JITM & 6 & EM & 6 & JINF & 4 \\
\hline 22 & IEEETSE & 23 & SMR & 12 & JACM & 5 & IM & 5 & OR & 4 \\
\hline 23 & JCIS & 22 & CAIS & 10 & MISQE & 4 & JIT & 5 & ACMTODS & 3 \\
\hline 24 & WIRT & 19 & ACMTOC & 9 & IP\&M & 4 & IEEES & 4 & AMR & 3 \\
\hline 25 & IEEEC & 17 & ASQ & 8 & JOC & 4 & INFSJ & 4 & EJIS & 3 \\
\hline & & & & & & \\
\hline
\end{tabular}


Table 3. This Study Compared to Other Ranking Studies

\begin{tabular}{|c|c|c|c|c|c|c|}
\hline Rank & This study & $\begin{array}{c}\text { (Mylonopolous } \\
\text { \& Theoharakis, } \\
\text { 2001) }\end{array}$ & $\begin{array}{l}\text { (Whitman et } \\
\text { al., 1999) }\end{array}$ & $\begin{array}{c}\text { (Hardgrave \& } \\
\text { Walstrom, 1997) }\end{array}$ & $\begin{array}{c}\text { (Holsapple et al., } \\
\text { 1994) }\end{array}$ & $\begin{array}{l}\text { (Gillenson \& } \\
\text { Stutz, 1991) }\end{array}$ \\
\hline 1 & MISQ & MISQ & MISQ & MISQ & MISQ & MS \\
\hline 2 & ISR & CACM & MS & ISR & CACM & MISQ \\
\hline 3 & JMIS & ISR & CACM & MS & MS & CACM \\
\hline 4 & MS & JMIS & ISR & CACM & HBR & DSCI \\
\hline 5 & CACM & MS & DSCI & JMIS & $\mathrm{I} \& \mathrm{M}$ & JMIS \\
\hline 6 & DSCI & IEEET & JMIS & DSCI & JMIS & JACM \\
\hline 7 & DSS & HBR & HBR & IEEETSE & SMR & ACMT \\
\hline 8 & IEEET & DSCI & IEEET & OS & Datamation & IEEET \\
\hline 9 & I\&M & DSS & SMR & HBR & IEEETSE & ACMCS \\
\hline 10 & ACMT & $\mathrm{I} \& \mathrm{M}$ & JACM & DSS & DSCI & HBR \\
\hline 11 & EJIS & EJIS & IEEEC & ACMTODS & ASQ (tied $\left.11^{\text {th }}\right)$ & IEEEC \\
\hline 12 & JAIS & SMR & ACMT & IEEET & DSS (tied $\left.11^{\text {th }}\right)$ & $\mathrm{I} \& \mathrm{M}$ \\
\hline 13 & ISJ & ACMT & DSS & SMR & AMJ & SMR \\
\hline 14 & OS & DATA BASE & ACMCS & ACMCS & ComputerWorld & JISM \\
\hline 15 & HBR & OS & I\&M & AMJ & ACMCS & ISYS \\
\hline 16 & $\mathrm{JOC}$ & ISJ & ISYS & ASQ & JSM & IRMJ \\
\hline 17 & OR & AMJ & DATA BASE & ACMT & Interfaces & JSM \\
\hline 18 & JSIS & CAIS & JISE & OR & $\mathrm{AI}$ & JIM \\
\hline 19 & JIS & IEEEC & Interfaces & AMR & ACMTODS & ACMSIG \\
\hline 20 & $\mathrm{I} \& \mathrm{O}$ & JSIS & IJHCS & I\&M & AMR & JCIS \\
\hline 21 & ISYS & ASQ & JDM & OBHDP & Database & JISCI \\
\hline 22 & IEEETSE & AMR & JIM & IJHCS & DATA BASE & JCSS \\
\hline 23 & JCIS & IJEC & OR & $\mathrm{HCI}$ & IJHCS & IP\&M \\
\hline 24 & WIRT & ACMCS & Omega & Omega & OR & SP\&E \\
\hline 25 & IEEEC & AMIT & JISCI & JSIS & IEEEC & CJ \\
\hline
\end{tabular}

Table 4. Top 15 Gobal Pactitioner Journals

\begin{tabular}{|c|l|c|}
\hline Rank & \multicolumn{1}{|c|}{ Journal } & Weight \\
\hline 1 & Comm. of the ACM (CACM) & 344 \\
\hline 2 & Harvard Bus. Review (HBR) & 273 \\
\hline 3 & Sloan Mgt Review (SMR) & 128 \\
\hline 4 & ComputerWorld (CW) & 71 \\
\hline 5 & CIO & 55 \\
\hline 6 & InformationWeek & 41 \\
\hline 7 & IEEE Computer (IEEEC) & 36 \\
\hline 8 & Interfaces & 32 \\
\hline 9 & Datamation & 17 \\
\hline 10 & IEEE Software (IEEES) & 17 \\
\hline 11 & MISQE & 16 \\
\hline 12 & DATA BASE & 15 \\
\hline 13 & IBM & 13 \\
\hline 14 & InfoWorld & 12 \\
\hline 15 & CAIS & 10 \\
\hline
\end{tabular}

Table 5. Top 15 Globally Read Journals

\begin{tabular}{|c|l|c|l|}
\hline Rank & Journal & Weight & Journal type \\
\hline 1 & ISR & 84 & Research \\
\hline 2 & MISQ & 69 & Research \\
\hline 3 & CACM & 48 & Practitioner/research \\
\hline 4 & JMIS & 26 & Research \\
\hline 5 & HBR & 24 & Practitioner/research \\
\hline 6 & MS & 20 & Research \\
\hline 7 & SMR & 20 & Practitioner/research \\
\hline 8 & IEEEC & 16 & Practitioner \\
\hline 9 & DSS & 14 & Research \\
\hline 10 & DSCI & 12 & Research \\
\hline 11 & I\&M & 11 & Research \\
\hline 12 & CW & 10 & Practitioner \\
\hline 13 & CIO & 9 & Practitioner \\
\hline 14 & JCIS & 9 & Research \\
\hline 15 & OS & 8 & Research \\
\hline
\end{tabular}


Table 6. Most Common Global IS Reference Disciplines

\begin{tabular}{|c|c|c|c|c|c|}
\hline Rank & $\begin{array}{l}\text { Reference } \\
\text { Discipline } \\
\text { Category }\end{array}$ & Sub-disciplines & $\begin{array}{c}\text { N }(\%) \\
\text { Total }= \\
1274\end{array}$ & Weight & $\begin{array}{c}\text { Table with } \\
\text { Journal } \\
\text { Rankings }\end{array}$ \\
\hline 1 & $\begin{array}{l}\text { Computer } \\
\text { Science }\end{array}$ & $\begin{array}{l}\text { Computer Science, Software Engineering, } \\
\text { Databases, Artificial Intelligence, Knowledge } \\
\text { Management, Security, Data Mining, Systems } \\
\text { Architecture, Networking, and Data Warehousing. }\end{array}$ & $\begin{array}{l}257 \\
(20 \%)\end{array}$ & 381 & Table 7 \\
\hline 2 & Business & $\begin{array}{l}\text { Business, Business Administration, Strategy, } \\
\text { Marketing, Management Science, Finance, and } \\
\text { International Business. }\end{array}$ & $\begin{array}{l}239 \\
(19 \%)\end{array}$ & 369 & Table 8 \\
\hline 3 & $\begin{array}{l}\text { Behavioral } \\
\text { Sciences }\end{array}$ & $\begin{array}{l}\text { Psychology, Sociology, Social Psychology, } \\
\text { Cognitive Psychology, Communication, Cognitive } \\
\text { Science, Behavioral Science, Social Sciences, } \\
\text { Behavioral Psychology, and Collaboration. }\end{array}$ & $\begin{array}{l}190 \\
(15 \%)\end{array}$ & 269 & Table 9 \\
\hline 4 & $\begin{array}{l}\text { Organization } \\
\text { Sciences }\end{array}$ & $\begin{array}{l}\text { Org. Behavior, Org. Theory, Org. Science, Org. } \\
\text { Psychology, Org. Development, and Org. } \\
\text { Learning. }\end{array}$ & $\begin{array}{l}122 \\
(10 \%)\end{array}$ & 200 & Table 10 \\
\hline 5 & $\begin{array}{l}\text { Decision } \\
\text { Sciences }\end{array}$ & $\begin{array}{l}\text { Decision Science, Decision Support Systems, } \\
\text { Operations Management, Operations Research, } \\
\text { Decision Theory, and Optimization. }\end{array}$ & $\begin{array}{l}101 \\
(7.5 \%)\end{array}$ & 148 & Table 11 \\
\hline 6 & $\begin{array}{l}\text { IS specialty } \\
\text { fields }\end{array}$ & $\begin{array}{l}\text { IS Strategy, IS Development, IS Planning, IS } \\
\text { Project Management, IS Management, } \\
\text { International dimensions of IS, Global IS, and } \\
\text { Management of Technology. }\end{array}$ & $\begin{array}{l}97 \\
(7.5 \%)\end{array}$ & 164 & $\mathrm{n} / \mathrm{a}$ \\
\hline 7 & Economics & $\begin{array}{l}\text { Economics, Information Economics, and } \\
\text { Evolutionary. }\end{array}$ & $\begin{array}{ll}78 \\
(6 \%)\end{array}$ & 124 & Table 12 \\
\hline 8 & E-commerce & $\begin{array}{l}\text { E-commerce, E-business, M-commerce, E- } \\
\text { commerce Strategies, and Electronic Markets. }\end{array}$ & $\begin{array}{l}60 \\
(5 \%) \\
\end{array}$ & 95 & Table 13 \\
\hline 9 & $\mathrm{HCI}$ & $\begin{array}{l}\text { HCI, CSCW, Usability, End-user computing, and } \\
\text { Human Factors. }\end{array}$ & $\begin{array}{ll}36 \\
(3 \%)\end{array}$ & 51 & $\mathrm{n} / \mathrm{a}$ \\
\hline 10 & Other & Other & $\begin{array}{l}25 \\
(2 \%)\end{array}$ & 32 & $\mathrm{n} / \mathrm{a}$ \\
\hline 11 & Education & $\begin{array}{l}\text { Education, E-learning, Distance Education, End } \\
\text { User Training, IS Education, and Innovative } \\
\text { Education. }\end{array}$ & $\begin{array}{l}22 \\
(2 \%)\end{array}$ & 28 & $\mathrm{n} / \mathrm{a}$ \\
\hline 12 & Philosophy & $\begin{array}{l}\text { Ontology, Philosophy, Ethics, Philosophy of } \\
\text { Science, Phenomenology, Policy and Ethics, Law, } \\
\text { and Semiotics. }\end{array}$ & $\begin{array}{l}17 \\
(1 \%)\end{array}$ & 28 & $\mathrm{n} / \mathrm{a}$ \\
\hline 13 & Accounting & $\begin{array}{l}\text { Accounting, Accounting Information Systems, } \\
\text { Auditing, Management Accounting }\end{array}$ & \begin{tabular}{|l|}
15 \\
$(1 \%)$ \\
\end{tabular} & 24 & $\mathrm{n} / \mathrm{a}$ \\
\hline 14 & Informatics & $\begin{array}{l}\text { Informatics, Information Science, Information } \\
\text { Quality, Information Theory, and Information } \\
\text { Policy. }\end{array}$ & $\begin{array}{ll}11 \\
(<1 \%)\end{array}$ & 17 & $\mathrm{n} / \mathrm{a}$ \\
\hline 15 & Health & $\begin{array}{l}\text { Healthcare, Health Care Management, and } \\
\text { Medical Informatics. }\end{array}$ & $\begin{array}{l}4 \\
(<1 \%)\end{array}$ & 7 & $\mathrm{n} / \mathrm{a}$ \\
\hline
\end{tabular}


Table 7. Top CS Journals for IS

\begin{tabular}{|c|l|l|l|}
\hline Rank & Journal & N (total=193) & Weight \\
\hline 1 & CACM & 28 & 48 \\
\hline 2 & IEEET & 23 & 35 \\
\hline 3 & ACMT & 16 & 24 \\
\hline 4 & IEEETSE & 11 & 19 \\
\hline 5 & ACMTODS & 9 & 17 \\
\hline 6 & IEEETKDE & 6 & 9 \\
\hline 7 & IEEEC & 4 & 7 \\
\hline 8 & Other journals & 96 & n/a \\
\hline
\end{tabular}

Table 8. Top Business Journals for IS

\begin{tabular}{|c|l|l|l|}
\hline Rank & \multicolumn{1}{|c|}{ Journal } & N (total=221) & Weight \\
\hline 1 & AMJ & 43 & 67 \\
\hline 2 & MS & 27 & 40 \\
\hline 3 & AMR & 19 & 29 \\
\hline 4 & ASQ & 14 & 23 \\
\hline 5 & HBR & 9 & 16 \\
\hline 6 & $\begin{array}{l}\text { Strategic } \\
\text { Management } \\
\text { Journal }\end{array}$ & 9 & 14 \\
\hline 7 & OS & 10 & 13 \\
\hline 8 & $\begin{array}{l}\text { Journal of } \\
\text { Marketing }\end{array}$ & 6 & 10 \\
\hline 9 & SMR & 5 & 8 \\
\hline 10 & Other journals & 79 & n/a \\
\hline
\end{tabular}

Table 9. Top Behavioral Science Journals for IS

\begin{tabular}{|c|l|l|l|}
\hline Rank & \multicolumn{1}{|c|}{ Journal } & N (total=81) & Weight \\
\hline 1 & JAP & 11 & 20 \\
\hline 2 & OS & 5 & 9 \\
\hline 3 & OBHDP & 5 & 7 \\
\hline 4 & Other journals & 60 & n/a \\
\hline
\end{tabular}

Table 10. Top Organization Journals for IS

\begin{tabular}{|c|l|l|l|}
\hline Rank & Journal & N (total=127) & Weight \\
\hline 1 & OS & 34 & 57 \\
\hline 2 & ASQ & 20 & 29 \\
\hline 3 & AMJ & 18 & 28 \\
\hline 4 & AMR & 13 & 18 \\
\hline 5 & MS & 4 & 8 \\
\hline 6 & OBHDP & 3 & 6 \\
\hline 7 & Other journals & 35 & n/a \\
\hline
\end{tabular}

Table 11. Top Decision Science Journals for IS

\begin{tabular}{|c|l|l|l|}
\hline Rank & Journal & N (total=74) & Weight \\
\hline 1 & MS & 13 & 24 \\
\hline 2 & DSS & 10 & 19 \\
\hline 3 & DSCI & 10 & 17 \\
\hline 4 & OR & 8 & 11 \\
\hline 5 & JOC & 4 & 7 \\
\hline 6 & Other journals & 29 & $\mathrm{n} / \mathrm{a}$ \\
\hline
\end{tabular}

Table 12. Top Economics Journals for IS

\begin{tabular}{|c|l|l|l|}
\hline Rank & \multicolumn{1}{|c|}{ Journal } & N (total=75) & Weight \\
\hline 1 & AER & 14 & 26 \\
\hline 2 & MS & 13 & 24 \\
\hline 3 & Other journals & 48 & n/a \\
\hline
\end{tabular}

Table 13. Top e-Commerce Journals for IS

\begin{tabular}{|c|l|l|l|}
\hline Rank & Journal & N (total=56) & Weight \\
\hline 1 & IJEC & 12 & 22 \\
\hline 2 & MISQ & 5 & 9 \\
\hline 3 & EM & 5 & 7 \\
\hline 4 & JMIS & 5 & 6 \\
\hline 5 & ISR & 4 & 6 \\
\hline 6 & MS & 4 & 6 \\
\hline 7 & Other journals & 21 & $\mathrm{n} / \mathrm{a}$ \\
\hline
\end{tabular}

\section{Discussion}

This study reveals some unexpected insights into the makeup of global IS departments, which further highlight the need to target active IS academics for such studies. The demographic data from this research indicate that global IS departments house many academics who have little or no involvement in the IS, as evidenced by the fact 2559 faculty responded from the 414 IS-related departments, yet only 1572 consider themselves to be active in the IS field and hold Ph.D.'s. The excluded academics who are not students often teach IS classes but do not actively contribute to IS conferences and journals. On the positive side, the data indicate that the IS field is highly dynamic and multidisciplinary, with many active IS researchers having joined the field from other disciplines. 
This research also contributes to the understanding of IS journal quality by summarizing opinions of active IS researchers throughout the world, and by breaking down the results by major world regions. This data reveal that there is general global agreement that MISQ and ISR are the top IS research journals. The data also create clear quality delineations between journals. For example, MISQ and ISR are clearly the leaders in overall IS research, while JMIS, Management Science (MS), and CACM provide the next tier of leading research journals. Moreover, the data reveal salient differences among world regions. North America, because of the large presence of active IS researchers, wields a strong overall influence (and bias) to the overall world rankings. North American academics tend to favor decision-science and MS oriented journals (e.g. DSCI, DSS, and MS) much more strongly than other academics. CACM is losing favor in North American more rapidly than other regions. European academics appear to favor more behavioral and practitioner journals than North American researchers.

By comparing this study to previous journal ranking studies (as seen in Table 3), several other important trends can be deduced. MISQ and ISR have persistently maintained their preeminent positions of intellectual leadership in the IS field over the past several years, with MISQ universally being considered the top IS research journal. JMIS and DSS have consistently moved up in prestige over time, while CACM and MS are slowly starting to drop in IS research importance (likely because of the increase in "pure" IS journals in recent years). Various IEEE transactions (IEEET) and various ACM transactions (ACMT) continue to be considered top outlets, especially in specialized areas such as databases and software engineering. Three journals are rapidly moving up in importance and are on a trajectory to challenge the leading IS journals: Information and Management (I\&M), European Journal of IS (EJIS), and Journal of the AIS (JAIS). The rise of JAIS, in particular, has been meteoric (except in Europe), which is likely attributable to its outstanding editorial board and strong association with the Association of IS (AIS), which has become the pre-eminent IS research organization. Several journals are significantly dropping in stature for IS research, such as: HBR, Sloan Management Review (SMR), and DATA BASE. Possible explanations for these change include that these journals treat IS as a special topic, while several newer journals, such as ISR and JMIS, have emerged to focus solely on the IS discipline.

This research also provides valuable insights into journal quality rankings by separating research and practitioner journal rankings. The data indicates that several journals appear to be hybrid journals, where they can be argued to represent both research and practitioner perspectives, as demonstrated by the fact they rank highly on both the research and practitioner rankings. Examples of hybrid journals include CACM, HBR, and SMR - with MISQ Executive (MISQE) and Communications of the AIS (CAIS) rapidly rising as quality hybrid journals. The results also indicate the top academic journals and top practitioner journals are the most highly read, and thus, are more likely to yield influence. While the IS research focus is less with CACM, HBR, and SMR than with journals such as ISR and MISQ, they are still highly read, and thus, are still highly influential. Moreover, ISR is read more than MISQ, which may indicate it is gaining ground on MISQ in terms of influence. Finally, while JAIS is a rising research journal, it is auspiciously absent from the top-25 reading list. In fact, the only electronic journal on the most-read list is CAIS, suggesting possible issues with access and/or readership influence of such electronic IS journals.

This research also provides a useful picture of the leading IS reference disciplines. Typical IS journal rankings do not incorporate well the most common IS reference disciplines (including sub-disciplines and research communities). For example, HCI and AI journals rarely appear highly in overall IS journal rankings, yet several of these journals are considered to be high quality in these fields. Thus, the reference journal rankings from this study not only provides unique insights into the structure of the IS field, but also provide useful information on the top reference discipline journals in which active IS researchers publish.

Despite the contributions of this research, it still has several limitations and areas for improvement. First, the results are based on perceptions of active IS researchers from survey data. This study does not widely use or consider other salient elements that can be used to define journal quality. Another key limitation is that the focus on selecting top journals creates a distribution that does not represent well middle-tier and low-tier journals. For example, a broader representation of high-, middle-, and lowtier journals is given by (Mylonopolous, 2001). Additionally, while the data on top journals for the primary IS reference disciplines are useful, it has limited generalizability because of the fragmented responses that occurred from the large distribution of reference disciplines. Furthermore, the large presence of active IS researchers in North America wields a strong overall influence (and bias) to the overall world rankings. On the other hand, this likely reflects on the reality of the IS world, especially considering a large portion of international IS researchers received their Ph.D. from U.S.-based institutions. Another possible issue is that since respondents declared their primary disciplines and reference disciplines, some biases may have occurred due to differences in terminology or due to their departments' naming conventions. Future research should likely delve into this potential issue to help further understand global discipline naming conventions. 


\section{Conclusion}

The results of this study, and the results any other rankings study, need to be used with caution and sound judgment, in conjunction with other forms of ratings data. Because no one study can realistically address all the elements of journal quality that are salient to all IS researchers and institutions, it may be most useful to conduct multiple ranking studies over time from different perspectives, from which IS researchers can use sound judgment to draw conclusions. Thus, this research reports IS journal rankings that are intended to be used in balance with previous ranking studies and other criteria, such as citation analysis, editorial board composition, rejection rates, and audience size. Thus, the results of this study should not be considered as the decisive perspective on journal rankings, but rather another perspective to be used judiciously.

While IS journals rankings studies can provide many benefits to the IS community, they also can be misused. Using journal rankings as part of tenure and promotion decisions may be the most controversial and abused application of journal rankings. In evaluating the quality of an academic's contribution to research, several approaches can be used: (1) evaluating the quality of the journals in which their articles appear; (2) counting the number of times one's works have been cited by others; (3) having external experts qualitatively evaluate the quality and contribution of one's articles; (4) counting the number of articles published by the academic; (5) evaluating external impact of one's work in terms of adoption by practitioners, use in classroom texts, patents, and citations by national press and television. All of these approaches are potentially flawed, especially when used as a sole or primary methodology, and can lead to misuse and unintended consequences. For example, while citation analysis can be effective in determining whether or not a work has any impact on other research, it is prejudiced by time. For example, most works that are considered "seminal" rarely achieve this status within the relatively short period it takes to make tenure and promotion decisions.

Inappropriate use of journal rankings can create other problems in promotion and tenure decisions. Articles are commonly judged in the short-term by the quality of the journal outlet in which it appears. This tends to be a useful heuristic because highquality journals are more likely to produce influential work than lower-quality journals. High-quality journals have the most visible and credible editorial review boards who insist on the highest intellectual standards. Additionally, as shown in this study, high-quality journals tend to have high readership, which also increases the probability of influence. Thus, because the true impact of a work takes years to develop, journal quality provides a useful surrogate for article quality in the short term. However, not everything that appears in a high quality journal is equal in quality and importance. Some works that appear in highly quality journals quickly fade into obscurity, and have no lasting influence on the academic community. Conversely, not everything in a lower quality journal is of low quality. Some innovative and highly influential works are published in lower-quality journals because they did not fit the intellectual paradigms or requirements of higher quality journals. Also, several researchers prefer to publish much of their work in lower quality journals, especially after they have become established in the IS community, because they can publish their ideas much more quickly than in high quality journals, which are notorious for lengthy, laborious review cycles.

Given the potential abuses of using journal rankings as a sole or primary basis of academic evaluations, we advocate the use of multiple evaluation methods, including the use of journal rankings. While some may consider journal rankings inherently dangerous, IS academics cannot escape the fact that academia is filled with subjective peer evaluation. We subjectively evaluate our students, we subjectively review and critique each others work, and we subjectively evaluate each other for promotion, reward, and tenure decisions. In evaluating the research of our peers, we can make these decisions blindly or use as many objective, external sources as possible to make better informed judgments. Journal rankings can help provide key evidence in this regard, but should not be the primary evidence.

\section{References}

Cooper, R. B., Blair, D., \& Pao, M. (1993). Communicating MIS research: A citation study of journal influence. Information Processing and Management, 29(1), 113-127.

Davis, G. B. (1980). A systematic evaluation of publications for promotion of MIS academics. Paper presented at the First International Conference on Information Systems, Philadelphia, PA.

Doke, E. R., \& Luke, R. H. (1987). Perceived quality of CIS/MIS journals among faculty: Publishing hierarchies. The Journal of Computer Information Systems, 28(4), 30-33.

Gillenson, M., \& Stutz, J. (1991). Academic issues in MIS: Journals and Books. MIS Quarterly (MISQ), 15(4), 447-452.

Hamilton, S., \& Ives, B. (1980). Communications of MIS research: An analysis of journal stratifications. Paper presented at the First International Conference on Information Systems, Philadelphia, PA. 
Hardgrave, B., \& Walstrom, K. (1997). Forums for MIS scholars. Communications of the ACM (CACM), 40(11), $119-124$.

Holsapple, C., Johnson, L., Manakyan, H., \& Tanner, J. (1994). Business computing research journals: A normalized citation analysis. Journal of Management Information Systems (JMIS), 11(1), 131-140.

Holsapple, C. W., Johnson, L. E., Manakyan, H., \& Tanner, J. (1993). A citation analysis of business computing research journals. Information and Management, 25, 231-244.

Holsapple, C. W., Manakyan, H., \& Tanner, J. (1995). An empirical assessment and categorization of journals relevant to DSS research. Decision Support Systems, 14, 359-367.

Mylonopolous, N. A., \& Theoharakis, V.(2001). On site: global perceptions of IS journals. Communications of the ACM(CACM), 44(99), 29-33.

Nord, J. H., \& Nord, D. G. (1995). MIS research: Journal status assessment and analysis. Information and Management, 29, 2942.

Nord, J. H., \& Nord, G. D. (1990). MIS research: A systematic evaluation of leading journals. IBSCUIG Quarterly, $2(2), 8-13$.

Robey, D., Walstrom, K., Adams, D., \& Swanson, B. (2000). Target journals for information systems research: Current practices and controversies (panel session). Paper presented at the International conference on Information systems.

Vogel, D. R., \& Wetherbe, J. C. (1984). MIS research: A profile of leading journals and universities. Database, 16(1), 3-14.

Walstrom, K., \& Hardgrave, B. (2001). Forums for information systems scholars:III. Information and Management, $39,117-124$.

Walstrom, K., Hardgrave, B., \& Wilson, R. (1995). Forums for management information systems scholars. Communications of the $A C M(C A C M), 38(3), 93-102$.

Whitman, M., Hendrickson, A., \& Townsend, A. (1999). Research commentary: Academic rewards for teaching, research and service: Data and discourse. Information Systems Research (ISR), 10(2), 99-109. 


\title{
Appendix 1. Journal Abbreviations
}

\author{
AMIT (Accounting, Management, and IT) \\ ACMCS (ACM Computing Surveys) \\ ACMSIG (various ACM SIG publications) \\ ACMT (various ACM Transactions) \\ ACMTCS (ACM Transactions on Computer Systems) \\ ACMTOCHI(ACM Trans. on Computer-Human Interaction) \\ ACMTODS (ACM Transactions on Database Systems) \\ ACMTOIS (ACM Transactions on IS) \\ ACMTSE (ACM Trans. on SE and Methodology) \\ AER (American Economic Review) \\ AI (Artificial Intelligence) \\ AMJ (Academy of Management Journal) \\ AMR (Academy of Management Review) \\ ASQ (Administrative Science Quarterly) \\ CACM (Communications of the ACM) \\ CAIS (Communications of the AIS) \\ CIO (CIO Magazine) \\ CMR (California Management Review) \\ CJ (Computer Journal) \\ CHDMP (Computers in Human Decision Making Processes) \\ DSCI (Decision Sciences) \\ DSS (Decision Support Systems) \\ ECR (E-commerce Research) \\ EJIS (European Journal of IS) \\ EJOR (European Journal of Operations Research) \\ EM (Electronic Markets Journal) \\ GDN (Group Decision and Negotiation) \\ HBR (Harvard Business Review) \\ HCI (Human-Computer Interaction) \\ I\&M (Information and Management) \\ I\&O (Information and Organization) \\ IBM (IBM Systems Journal) \\ IEEEC (IEEE Computer) \\ IEEES (IEEE Software) \\ IEEET (various IEEE Transactions) \\ IEEETKDE (IEEE Trans. on Knowledge and Data \\ Engineering) \\ IEEETPC (IEEE Trans. on Professional Communication) \\ IEEETSE (IEEE Transactions on Software Engineering) \\ IEEETSMC (IEEE Trans. on Systems, Man, \& Cybernetics) \\ IJEC (International Journal of Electronic Commerce) \\ IJHCI (International Journal of Human Computer Interaction) \\ IJHCS (International Journal of Human Computer Studies) \\ IM (International Journal of Information Management) \\ ISOC (Information Society) \\ INFSJ (Informing Science Journal) \\ Interfaces (the Interfaces journal by INFORMS) \\ IP\&M (Information Processing and Management) \\ IRMJ (Information Resources Management Journal) \\ ISJ (Information Systems Journal) \\ ISR (Information Systems Research) \\ ISYS (Information Systems) \\ IT\&P (Information Technology and People) \\ JACM (Journal of the ACM) \\ JAIS (Journal of the AIS) \\ JAP (Journal of Applied Psychology) \\ JAR (Journal of Accounting Research) \\ JCIS (Journal of CIS) \\ JCMC (Journal of Computer-Mediated Communication) \\ JDM (Journal of Database Management) \\ JEC (Journal of Electronic Commerce) \\ JECR (Journal of Electronic Commerce Research) \\ JEUC (Journal of End User Computing) \\ JIM (Journal of Information Management) \\ JIS (Journal of Information Systems) \\ JISE (Journal of Information Systems Education) \\ JISM (Journal of Information Systems Management) \\ JIT (Journal of IT) \\ JITM (J IT Management) \\ JMIS (Journal of MIS) \\ JOC (Journal on Computing) \\ JOCEC (Journal of Org. Computing \& e-Commerce) \\ JCSS (Journal of Computer and System Science) \\ JINF (Journal of Informatics) \\ JISCI (Journal of Information Science) \\ JSM (Journal of Systems Management) \\ JSIS (Journal of Strategic Information Systems) \\ MISQ (MIS Quarterly) \\ MISQE (MISQ Executive) \\ MS (Management Science) \\ OBHDP (Org. Behavior and Human Decision Process) \\ OR (Operations Research) \\ OS (Organization Science) \\ SMR (Sloan Management Review) \\ SP\&E (Software Practice and Experience) \\ WIRT (Wirtschaftsinformatik)
}

IJPR (International Journal of Production Research) 